\title{
Production of Tamarindus indica L. seedlings submitted to substrates and pre-germination methods ${ }^{1}$
}

\author{
Camile Dutra Lourenço Gomes², Jolinda Mércia de Sá2, \\ Marília Hortência Batista Silva Rodrigues ${ }^{3}$, Valéria Fernandes de Oliveira Sousa ${ }^{3}$, Marinês Pereira Bomfim²
}

\begin{abstract}
The tamarind tree has problems of seed germination, and methods to overcome it are necessary. This study aimed to evaluate substrates and pre-germination methods in the production of tamarind seedlings. The experiment was carried out in a protected environment, using a randomized block experimental design, in a $5 \times 4$ factorial scheme, corresponding to five pre-germination methods (mechanical scarification with sandpaper and imbibition in water for $24 \mathrm{~h}$, tegument cut and soaking in water for $24 \mathrm{~h}$, soaking in water for $24 \mathrm{~h}$, seed soaked in water with Trichoderma harzianum for $24 \mathrm{~h}$ and seed soaked in water containing $T$. longibrachiatum for $24 \mathrm{~h}$ ) and four substrates [100\% of soil, soil + commercial substrate $(3: 2)$, soil + bovine manure $(3: 2)$ and soil + goat manure $(3: 2)]$. The use of substrates formulated with soil + bovine manure and soil + goat manure in the production of Tamarindus indica L. seedlings provides a higher growth. The pre-germination methods of mechanical scarification and the use of seed soaking in both Trichodermas positively influence the growth and quality of seedlings.
\end{abstract}

KEYWORDS: Tamarindus indica L., seed dormancy, manure.

\section{INTRODUCTION}

The tamarind tree (Tamarindus indica L.) is an exotic tropical fruit tree native of tropical Africa and is highly adaptable to the Brazilian soil and climatic conditions (Góes et al. 2016). Due to the presence of a deep root system and resistance to prolonged drought, its cultivation is indicated for semi-arid regions such as the Brazilian Northeast (Costa et al. 2012). It is an arboreal plant, diffused as an important food source, and the fruit pulp is consumed in natura or used in the preparation of juices, ice creams, liqueurs

\section{RESUMO}

Produção de mudas de Tamarindus indica L. submetidas a substratos e métodos pré-germinativos

O tamarindeiro possui problemas na germinação de sementes, necessitando de métodos para a superação da mesma. Objetivou-se avaliar substratos e métodos pré-germinativos na produção de mudas de tamarindeiro. $\mathrm{O}$ experimento foi conduzido em ambiente protegido, com delineamento experimental em blocos casualizados, em esquema fatorial $5 \times 4$, correspondente a cinco métodos pré-germinativos (escarificação mecânica com lixa e embebição em água por $24 \mathrm{~h}$, corte do tegumento e embebição em água por $24 \mathrm{~h}$, embebição em água por $24 \mathrm{~h}$, semente embebida em água com Trichoderma harzianum por $24 \mathrm{~h}$ e semente embebida em água contendo $T$. longibrachiatum por $24 \mathrm{~h}$ ) e quatro substratos [100\% de solo, solo + substrato comercial (3:2), solo + esterco bovino (3:2) e solo + esterco caprino (3:2)]. O uso de substratos formulados com solo + esterco bovino e solo + esterco caprino na produção de mudas de Tamarindus indica L. proporciona maior crescimento. Os métodos pré-germinativos de escarificação mecânica e a utilização de embebição da semente em ambos os Trichodermas influenciam positivamente no crescimento e qualidade das mudas.

PALAVRAS-CHAVE: Tamarindus indica L., dormência de semente, esterco.

and candies. Several studies have pointed out that the fruits of this species present pharmacological and nutraceutical properties, among these antiinflammatory and analgesic actions, and they are effective in the treatment of headaches and stress symptoms (Souza et al. 2010, Suralkar et al. 2012).

The tamarind tree is a perennial plant, and the process of producing quality seedlings is fundamental to the future success of its commercial exploitation. The main propagation method used by producers is seminal (Dantas et al. 2012). However, this species presents integumentary dormancy, and the

1. Received: Jul. 16, 2018. Accepted: May 29, 2019. Published: Jul. 01, 2019. DOI: 10.1590/1983-40632019v4954029.

2. Universidade Federal de Campina Grande, Pombal, PB, Brasil. E-mail/ORCID: camiledutralg@gmail.com/ 0000-0003-2718-6178, jolindamercia@gmail.com/0000-0003-4953,mpbfito@gmail.com/0000-0003-2424-3843.

3. Universidade Federal da Paraíba, Areia, PB, Brasil.E-mail/ORCID: marilia_agroecologa@hotmail.com/ 0000-0003-3032-7269, valeriafernandesbds@gmail.com/0000-0002-6124-0898. 
impermeability of the integument to water or gases represents the most common dormancy mechanism, and may reach up to $98 \%$ of the seeds (Carvalho \& Nakagawa 2012). Thus, it is necessary to use efficient pre-germination treatments to overcome dormancy, in order to provide a high germination percentage (Baskin \& Baskin 2014).

The overcoming of integumentary dormancy by physical and chemical methods has been evaluated in tamarind seeds. In a study by Oliveira et al. (2017), the method of seed immersion in sulfuric acid for 15 min was the most efficient for promoting an increase in the percentage of germination to values close to $100 \%$. Segato et al. (2017) concluded that mechanical scarification plus immersion in water for $24 \mathrm{~h}$ promoted an emergence percentage of $67 \%$.

The use of fungi of the Trichoderma spp. genus as a method of breaking dormancy is highlighted by the bioprotective and plant growth promoting action, providing protection against the attack of pathogens in the germination process, seedling vigor and benefiting seed germination. Studies show that Trichoderma isolates have led to significant increases in the percentage and emergence speed in tomato tree, wheat and Pelptophorum dubium (Spreng.) Taub (Junges et al. 2016, França et al. 2017, Repas et al. 2017).

In order to guarantee the development of a plant with quality at a low cost (Mesquita et al. 2012), the knowledge of the ideal substrate for the seedling production is necessary. Therefore, the physical and chemical quality of the substrate influence the performance of the plants, mainly at this stage of development, in which the plant is very sensitive to the attack of microorganisms and not tolerant to the water deficit, and these must present characteristics that favor the moisture retention and availability of nutrients to meet the physiological needs of plants (Gomes et al. 2015).

It was observed that the mixture of soil with manure (bovine, goat and sheep) is favorable for the formation and development of tamarind seedlings grown on different substrates (Mendonça et al. 2014). However, studies aimed at determining methods of overcoming dormancy associated with the use of suitable substrates for the good establishment of tamarind seedlings are incipient.

The study of substrates and methods of overcoming dormancy are primordial in the process of seedling production, and the treatment efficiency is variable according to the species and environmental conditions (Abreu et al. 2017). Therefore, this study aimed to evaluate the influence of pre-germination methods and cultivation substrates on the production of tamarind seedlings.

\section{MATERIAL AND METHODS}

The experiment was carried out from March to June 2017, in a greenhouse with dimensions of $24 \mathrm{~m} \times 10 \mathrm{~m} \times 3.5 \mathrm{~m} \times 4.5 \mathrm{~m}$ (length, width, right foot and center height, respectively) and covered with a $120 \mu \mathrm{m}$ thick diffuser film, with anti-UV additives, installed at the Universidade Federal de Campina Grande, in Pombal, Paraíba state, Brazil (06\%46'13"S, $37^{\circ} 48^{\prime} 06^{\prime \prime} \mathrm{W}$ and $184 \mathrm{~m}$ of altitude). According to the Köppen climatic classification, adapted to Brazil (Coelho \& Soncin 1982), the climate of the region is $\mathrm{BSh}$, representing a hot and dry semiarid climate, with average precipitation of 700-900 $\mathrm{mm}_{\text {year }}{ }^{-1}$, annual average temperature of $26.1{ }^{\circ} \mathrm{C}$ and annual average evaporation of 1,000-1,100 mm (Francisco \& Santos 2017).

The experimental design was randomized blocks, in a $5 \times 4$ factorial scheme, being five pregermination methods (mechanical scarification with sandpaper and soaking in water for $24 \mathrm{~h}$, tegument cut and soaking in water for $24 \mathrm{~h}$, imbibition in water for $24 \mathrm{~h}$, seed soaked in water with Trichoderma harzianum for $24 \mathrm{~h}$ and seed soaked in water containing T. longibrachiatum for $24 \mathrm{~h}$ ) and four substrates $[100 \%$ of soil, soil + commercial substrate Basaplant Solaris ${ }^{\circledR}(3: 2)$, soil + bovine manure (3:2) and soil + goat manure $(3: 2)]$, with six replicates.

The soil was collected from the $0-20 \mathrm{~cm}$ layer and characterized as a Fluovian Neosol, and the bovine and goat manures were previously tanned before the experimental installation. The chemical characterization of the soil and other components for the formulation of the substrates was carried out using methodologies by Embrapa (1997). The results of the sample analyzes are shown in Table 1.

The seeds used were extracted from fruits in complete maturity stage and properly healthy, purchased in the local commerce of Pombal, Paraíba state, Brazil. The seeds extraction was done manually, then they were washed in tap water to remove the pulp, with the help of a fine mesh sieve, and placed on a bench, on two sheets of paper towel, to dry under laboratory conditions, for $48 \mathrm{~h}$. 
Table 1. Chemical characteristics of the soil samples and substrates used to evaluate the production of tamarind tree seedlings.

\begin{tabular}{lccccccccccrrr}
\hline \multirow{2}{*}{ Substrate } & $\begin{array}{c}\mathrm{pH}\left(\mathrm{H}_{2} \mathrm{O}\right) \\
1: 2.5\end{array}$ & \multicolumn{1}{c}{$\mathrm{EC}$} & \multicolumn{1}{c}{$\mathrm{P}$} & $\mathrm{N}$ & $\mathrm{K}$ & $\mathrm{Na}$ & $\mathrm{Ca}$ & $\mathrm{Mg}$ & $\mathrm{Al}$ & $\mathrm{H}+\mathrm{Al}$ & $\mathrm{SB}$ & $\mathrm{CEC}$ & $\mathrm{OM}$ \\
\hline $\mathrm{S}$ & 6.50 & 0.32 & 16.00 & 1.00 & 1.39 & 0.61 & 2.70 & 2.50 & 0.00 & 0.32 & 7.20 & 8.21 & 16.0 \\
$\mathrm{BM}$ & 6.47 & 1.09 & 98.00 & 2.40 & 3.80 & 1.54 & 4.52 & 2.63 & 0.00 & 0.00 & 12.50 & 10.90 & 40.0 \\
$\mathrm{BM}$ & 7.26 & 0.74 & 2.86 & 3.80 & 2.68 & 4.50 & 2.60 & 2.93 & 0.00 & 0.00 & 14.50 & 11.72 & 42.0 \\
$\mathrm{BSC}$ & 5.80 & 1.41 & 315.00 & - & 468.00 & 6.60 & 15.60 & 9.50 & 0.00 & 6.60 & 142.00 & 33.00 & 8.2 \\
\hline
\end{tabular}

pH: hydrogenation potential; EC: electrical conductivity; P: phosphorus, N: nitrogen; Na: sodium; Ca: Calcium, Mg: Magnesium; Al: aluminum; H: hydrogen; SB: sum

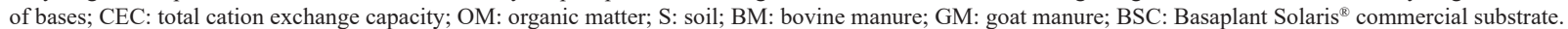

The Trichoderma (Trichoderma harzianum Trichobio in the concentration of 2 x 108 CFU; and Trichoderma longibrachiatum - Trichonemat in the concentration of $2 \times 108 \mathrm{CFU}$ ) was provided by the company BIOFUNGI - Biological Control, Eunápolis - Bahia state, Brazil. The treated seeds were sown in black polyethylene bags $(15 \mathrm{~cm} \mathrm{x}$ $21 \mathrm{~cm}$ ), placing two seeds per bag at a depth of $2 \mathrm{~cm}$. After planting, the seedlings were thinned at 30 days after sowing (DAS), leaving only the most vigorous one per container. During the experimental conduction, manual weeding was performed to avoid competition with the main crop. Irrigation was performed daily, using the drainage lysimetry methodology, so that the substrate remained close to field capacity throughout the conduction of the experiment, according to the following formula: $\mathrm{Vi}=(\mathrm{Va}-\mathrm{Vd}) /(1-\mathrm{LF})$, where $V i$ is the volume to be irrigated, $V a$ the applied volume, $V d$ the drained volume and $L F$ the leaching factor $(10 \%)$.

At 100 DAS, the following growth characteristics were determined:

- Height: measured with a ruler graduated in millimeters, from the base to the top of the plant stem;

- Number of leaves: determined by counting the expanded and fully formed leaves, with results expressed in number of leaves per plant;

- Stem diameter: determined at $5 \mathrm{~cm}$ above the ground, on the plant collar, using a digital caliper, with results expressed in millimeters;

- Root length: for measuring the root length $\left(\right.$ seedling $\left.^{-1}\right)$, a ruler graduated in millimeters was used;

- Plant dry mass (shoot, root and total): the seedlings were separated into shoot and root and placed in kraft paper bags, and later they were conditioned in a forced air circulation oven at the temperature of $65^{\circ} \mathrm{C}$, until reaching a constant weight (approximately $48 \mathrm{~h}$ ). Then, they were weighed in a precision analytical scale $(0.001 \mathrm{~g})$. The total dry mass was determined by the sum of the shoot and root dry mass, with the average results expressed in grams per plant;

- Biomass production: determined based on the plant dry mass (Emon et al. 2015), expressed by the following formula: $\mathrm{BP}=(\mathrm{TDM} / \mathrm{TFM})$ $194 \times 100$, where TDM is the plant total dry mass and TFM the total fresh mass, with results expressed as percentage;

- Dickson quality index: to evaluate the quality of the seedlings, the methodology described by Dickson et al. (1960) was used, applying the following formula: DQI $=\mathrm{TDM} /[(\mathrm{H} / \mathrm{CD})+(\mathrm{SDM} /$ $\mathrm{RDM})]$, where $T D M$ is the total dry mass ( $\mathrm{g}), H$ the height $(\mathrm{cm}), C D$ the collar diameter $(\mathrm{mm}), S D M$ the shoot dry mass (g) and RDM the root dry mass (g).

The results were submitted to analysis of variance, and the means were compared using the statistical Sisvar software, version 5.6 (Ferreira 2014).

\section{RESULTS AND DISCUSSION}

There was interaction between the evaluated factors on all the growth traits analyzed, except for stem diameter, demonstrating that the pre-germination methods and substrates simultaneously interfered in the growth of tamarind seedlings (Table 2).

The height of the tamarind seedlings showed a significant effect on the interaction between the factors, where, for the substrate soil, only the pregermination method imbibition in water containing T. longibrachiatum for $24 \mathrm{~h}$ was the best one, not differing from the dormancy overcoming only with imbibition of water in the seed (Table 3). Probably, the integumentary physical breakdown may have damaged the seed embryo, favoring the use of seed imbibition methodologies. In the other substrates, greater increases were also observed in the height with the use of seed imbibition in both Trichodermas. Trichoderma has a dormancy breaking action, since 
it erodes the funiculus, reducing its resistance and promoting acceleration in the germination process and, consequently, in the seedling growth (DelgadoSánchez et al. 2011). In addition, it provides biostimulating actions on the plant subsequent growth (Swain et al. 2018), explaining this fact.

It was also found that the use of substrate formulation with bovine and goat manure resulted in higher seedling heights in all dormancy-breaking methods. The manure applied to the substrate formulation is one of the several organic sources used in agriculture, due to the improvement of the physical, chemical and biological properties of the substrate (Aguiar et al. 2012, Mesquita et al. 2012), what contributed to a greater increase in the height of tamarind seedlings.

Regarding the number of leaves, it was verified that, in the substrate formulations with $100 \%$ of soil and soil + commercial substrate Basaplant Solaris $^{\circledR}(3: 2)$, the pre-germination of seeds with imbibition in water containing $T$. longibrachiatum for $24 \mathrm{~h}$ was the best for leaf emission (Table 3 ). Machado et al. (2012) report that the increase in growth provided by the application of Trichoderma may be in its ability to solubilize important nutrients for the plant development. Therefore, the action of this fungus as a growth stimulant is complex and is performed by interactions with biochemical factors and productions of various enzymes and beneficial compounds.

When analyzing the substrate soil + bovine manure (3:2), the use of dormancy breaking with seed soaked in water and in both Trichodermas presented a larger number of leaves, while, in the substrate soil + goat manure (3:2), the mechanical scarification and the use of the two Trichodermas in overcoming dormancy led to an increase in this same variable.

It was found that the substrates with formulations containing bovine and goat manure promoted a greater number of leaves in the tamarind seedlings in all the pre-germination methods. The commercial substrate, despite having a high

Table 2. Summary of the variance analysis for height, number of leaves (NL), stem diameter (SD), root length (RL), shoot (SDM), root (RDM) and total (TDM) dry mass, biomass production (BP) and Dickson quality index (DQI) in the production of tamarind seedlings, as a function of pre-germination methods and substrates.

\begin{tabular}{|c|c|c|c|c|c|c|c|c|c|c|}
\hline \multirow{2}{*}{ SV } & \multirow{2}{*}{$\mathrm{DF}$} & \multicolumn{9}{|c|}{ Medium square } \\
\hline & & Height $(\mathrm{cm})$ & NL & $\mathrm{SD}(\mathrm{mm})$ & $\mathrm{RL}(\mathrm{cm})$ & $\operatorname{SDM}(\mathrm{g})$ & RDM (g) & TDM $(\mathrm{g})$ & $\mathrm{BP}(\%)$ & DQI \\
\hline $\mathrm{M}$ & 4 & $477.23 * *$ & $480.41 * *$ & $0.96 * *$ & $234.82 * *$ & $1.48 * *$ & $0.10^{*}$ & $1.47 * *$ & $362.79 * *$ & $0.005 * *$ \\
\hline $\mathrm{S}$ & 3 & $1,219.28 * *$ & $2,619.83 * *$ & $1.09 * *$ & $107.32 * *$ & $14.67 * *$ & $0.11^{*}$ & $15.57 * *$ & $176.39 * *$ & $0.01 * *$ \\
\hline$M \times S$ & 12 & $303.86^{* *}$ & $238.79 * *$ & $0.26^{\mathrm{ns}}$ & $194.95 * *$ & $2.19 * *$ & $0.48 * *$ & $4.24 * *$ & $475.67 * *$ & $0.005 * *$ \\
\hline Block & 5 & $16.96^{\mathrm{ns}}$ & $9.35^{\mathrm{ns}}$ & $0.26^{\mathrm{ns}}$ & $17.89^{\text {ns }}$ & $0.39^{\mathrm{ns}}$ & $0.06^{\mathrm{ns}}$ & $0.56^{\mathrm{ns}}$ & $61.51 *$ & $0.001^{\mathrm{ns}}$ \\
\hline Residue & 95 & 13.40 & 10.70 & 0.18 & 12.67 & 0.17 & 0.03 & 0.26 & 26.38 & 0.001 \\
\hline Total & 119 & & & & & & & & & \\
\hline CV (\%) & & 11.32 & 11.53 & 14.50 & 14.47 & 22.31 & 27.82 & 19.76 & 14.45 & 19.81 \\
\hline Average & & 32.33 & 28.38 & 2.99 & 24.60 & 1.88 & 0.69 & 2.58 & 35.54 & 0.18 \\
\hline
\end{tabular}

Table 3. Height and number of leaves per plant in the production of tamarind seedlings, as a function of pre-germination methods and substrates.

\begin{tabular}{|c|c|c|c|c|c|c|c|c|}
\hline \multirow{2}{*}{$\begin{array}{l}\text { Pre-germination } \\
\text { methods }\end{array}$} & \multicolumn{4}{|c|}{ Height $(\mathrm{cm})$} & \multicolumn{4}{|c|}{ Number of leaves } \\
\hline & $\mathrm{S}_{1}$ & $\mathrm{~S}_{2}$ & $\mathrm{~S}_{3}$ & $\mathrm{~S}_{4}$ & $\mathrm{~S}_{1}$ & $\mathrm{~S}_{2}$ & $\mathrm{~S}_{3}$ & $\mathrm{~S}_{4}$ \\
\hline $\mathrm{M}_{1}$ & $31.05 \mathrm{ABCb}$ & $10.00 \mathrm{Bc}$ & $36.84 \mathrm{Ba}$ & $37.90 \mathrm{Ba}$ & $18.05 \mathrm{Bb}$ & $8.16 \mathrm{Cc}$ & $41.20 \mathrm{Aa}$ & $38.88 \mathrm{Aa}$ \\
\hline $\mathrm{M}_{2}$ & $25.25 \mathrm{Cb}$ & $27.75 \mathrm{Ab}$ & $14.50 \mathrm{Cc}$ & $39.90 \mathrm{Ba}$ & $19.23 \mathrm{Bb}$ & $18.83 \mathrm{Bb}$ & $18.00 \mathrm{Bb}$ & $31.83 \mathrm{Ba}$ \\
\hline $\mathrm{M}_{3}^{2}$ & $32.66 \mathrm{ABb}$ & $25.00 \mathrm{Ac}$ & $39.33 \mathrm{ABa}$ & $35.66 \mathrm{Bab}$ & $21.83 \mathrm{Abc}$ & $18.66 \mathrm{Bc}$ & $41.33 \mathrm{Aa}$ & $30.00 \mathrm{Bb}$ \\
\hline $\mathrm{M}_{4}$ & $28.83 \mathrm{BCb}$ & $30.00 \mathrm{Ab}$ & $43.83 \mathrm{Aa}$ & $40.66 \mathrm{ABa}$ & $22.83 \mathrm{ABb}$ & $22.00 \mathrm{Bb}$ & $41.66 \mathrm{Aa}$ & $40.50 \mathrm{Aa}$ \\
\hline $\mathrm{M}_{5}^{4}$ & $36.83 \mathrm{Ab}$ & $29.66 \mathrm{Ac}$ & $36.33 \mathrm{Bb}$ & $45.50 \mathrm{Aa}$ & $26.66 \mathrm{Ab}$ & $29.00 \mathrm{Ab}$ & $38.00 \mathrm{Aa}$ & $43.00 \mathrm{Aa}$ \\
\hline
\end{tabular}

$\mathrm{M}_{1}$ : mechanical scarification with sandpaper and imbibition in water for $24 \mathrm{~h} ; \mathrm{M}_{2}$ : tegument cut and soaking in water for $24 \mathrm{~h}$; $\mathrm{M}_{3}$ : soaking in water for $24 \mathrm{~h}$; $\mathrm{M}_{4}$ : seed soaked in water with Trichoderma harzianum for $24 \mathrm{~h} ; \mathrm{M}_{5}$ : seed in water containing T. longibrachiatum for $24 \mathrm{~h}$. Substrates: $\mathrm{S}_{1}: 100 \%$ of soil; $\mathrm{S}_{2}$ : soil + commercial substrate Basaplant Solaris ${ }^{\circledR}(3: 2) ; \mathrm{S}_{3}$ : soil + bovine manure $(3: 2) ; \mathrm{S}_{4}$ : soil + goat manure $(3: 2)$. * Means followed by the same capital letter in the column and lowercase letter in the row do not differ statistically from each other by the Tukey test at $5 \%$ of probability. 
content of nutrients such as phosphorus, potassium and organic matter, resulted in a lower number of leaves, a behavior that may be related to the electrical conductivity of $1.41 \mathrm{dS} \mathrm{m}^{-1}$ (Table 1), which decreases the osmotic potential of the substrate solution, making it difficult to absorb the nutrients present in the substrate.

The increase provided by the substrates consisting of manure formulations is due to the fact that these sources are nutritionally rich, because they present high levels of organic matter, as well as a greater humidity retention and increase in the cation exchange capacity (Yuan et al. 2018). Corroborating this study, Pereira et al. (2016), evaluating substrates in the production of tamarind tree rootstock, found that the goat manure was the most suitable for the production of tamarind tree rootstock.

In the caulinar diameter, it was verified that the use of mechanical scarification and seed imbibition in Trichoderma longibrachiatum for $24 \mathrm{~h}$ were superior, in relation to the other types of dormancy overcoming, obtaining a smaller diameter in the tegument cut method (Table 4). The mechanical scarification with sandpaper and tegument cut are techniques widely used for the overcoming of integumentary dormancy; however, although inexpensive, it requires knowledge of the seed morphology to avoid excessive scarification, causing seed damage and negatively influencing the

Table 4. Stem diameter in the production of tamarind seedlings due to pre-germination methods and substrates.

\begin{tabular}{cc}
\hline Pre-germination methods & Stem diameter $(\mathrm{cm})$ \\
\hline $\mathrm{M}_{1}$ & $3.15 \mathrm{~A}$ \\
$\mathrm{M}_{2}$ & $2.73 \mathrm{~B}$ \\
$\mathrm{M}_{3}$ & $2.87 \mathrm{AB}$ \\
$\mathrm{M}_{4}$ & $2.97 \mathrm{AB}$ \\
$\mathrm{M}_{5}$ & $3.21 \mathrm{~A}$ \\
\hline Substrates \\
$\mathrm{S}_{1}$ & $2.81 \mathrm{~B}$ \\
$\mathrm{~S}_{2}$ & $2.84 \mathrm{~B}$ \\
$\mathrm{~S}_{3}$ & $3.10 \mathrm{AB}$ \\
$\mathrm{S}_{4}$ & $3.20 \mathrm{~A}$
\end{tabular}

$\mathrm{M}_{1}$ : mechanical scarification with sandpaper and imbibition in water for $24 \mathrm{~h} ; \mathrm{M}_{2}$ : tegument cut and soaking in water for $24 \mathrm{~h} ; \mathrm{M}_{3}$ : soaking in water for $24 \mathrm{~h} ; \mathrm{M}_{4}^{2}$ : seed soaked in water with Trichoderma harzianum for $24 \mathrm{~h} ; \mathrm{M}_{5}$ : seed in water containing Trichoderma longibrachiatum for 24 h. $\mathrm{S}_{1}: 100 \%$ of soil; $\mathrm{S}_{2}$ : soil +

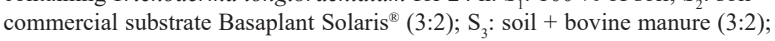
$\mathrm{S}_{4}$ : soil + goat manure (3:2). * Means followed by the same capital letter in the column do not differ statistically from each other by the Tukey test at $5 \%$ of probability. germination or providing less vigorous seedlings, possibly explaining the smaller diameter with tegument cut (Lima et al. 2013). While the use of Trichoderma in the seed stimulates the expression of genes related to the plant defense, it acts as a stimulator in the production of leaves, accumulation of photoassimilates and greater development of the pivoting root and radicels, thus reflecting on the caulinar diameter (Harman et al. al. 2004), and it is a method of dormancy overcoming that exposes the seeds to lower risks of physical integrity and physiological quality (Delgado-Sánchez et al. 2010).

In relation to the influence of the substrates (Table 4) on the stem diameter, it was observed that the substrate with soil + goat manure $(3: 2)$ presented a larger diameter in the seedlings. The use of goat manure is a way of better nutritional utilization, since it has a slower release of nutrients than the most commonly used ones (poultry and bovine litter) (Souza et al. 2017). Mendonça et al. (2014), when evaluating substrates in tamarind rootstocks, concluded that the combination of soil with goat and bovine manure presented satisfactory results, whereas the substrate with only soil showed a lower growth.

For the root length data of tamarind seedlings (Table 5), it was found that, in the substrate composed only of soil, there was no significant difference between the types of dormancy overcoming. In the formulation of soil and commercial substrate mixture, the mechanical scarification presented a lower root length, when compared to the others, while, in the substrate soil + bovine manure, the use of tegument cut in the seed provided less length, in relation to the other pre-germination methods, and the substrate formulated with soil + goat manure presented no differences with the different pre-germination methods.

Similarly, the shoot dry mass of tamarind plants also had a significant effect on the interaction between the pre-germination methods and substrates. Using only soil, there was no significant difference between the types of dormancy. However, in the soil + commercial substrate formulation, the use of mechanical scraping presented a lower dry mass, in relation to the other methods, while, in the substrate formulated with soil + bovine manure, the lowest quantity of dry mass was observed with the use of tegument cut, and in the substrate soil + goat manure the imbibition method presented the lowest quantity of dry mass (Table 5). 
For root length and shoot dry mass, the use of mechanical scarification with sandpaper and tegument cut influenced negatively the soil + commercial soil and soil + bovine manure, respectively. Probably, these types of dormancy overcoming in these substrates did not favor the root growth and, consequently, the shoot growth of the seedlings. This fact may be related to the electrical conductivity of both substrates $\left(1.09 \mathrm{dS} \mathrm{m}^{-1}\right.$ and $\left.1.41 \mathrm{dS} \mathrm{m}^{-1}\right)$ in the form of bovine manure and commercial substrate, respectively, and these pre-germination methods have damaged some regions of the seed embryo during the physical breaking.

Segato et al. (2017), studying types of pregermination methods in seeds of Tamarindus indica, observed that the mechanical scarification with sandpaper plus immersion in water for $24 \mathrm{~h}$ did not differ statistically from the control. The authors also report that, when analyzing the sanity of the tamarind seeds, they verified the presence of fungi, and this may have interfered in the emergence of the plants, not expressing statistical superiority with the use of the pre-germination method. Supposedly, the use of seed imbibition in Trichoderma, besides overcoming the dormancy, has an antagonistic action to other pathogenic fungi and attenuates abiotic stresses, in this case with a high salt content, which may have provided a greater growth in most of the evaluated characteristics (Mastouri et al. 2010, Junges et al. 2016).

Analyzing the root dry matter accumulation (Table 6), it was verified that, in the substrate containing soil, only the use of tegument cut provided a better root dry mass accumulation, while the soil and commercial substrate mixing was better with the pre-germination methods for tegument cut, seed soaking in water and seed soaking with Trichoderma harzianum. The substrate soil + bovine manure with mechanical scarification and imbibition of the seed with $T$. harzianum increased the root dry mass, and in the substrate soil + goat manure the tegument cut promoted a greater root dry mass accumulation.

Concerning the total dry mass (Table 6), the substrate with $100 \%$ of soil did not present any difference with the pre-germination methods; however, the commercial soil substrate with the

Table 5. Root length and shoot dry mass in the production of tamarind seedlings, as a function of pre-germination methods and substrates.

\begin{tabular}{crrrrrrrc}
\hline \multirow{2}{*}{$\begin{array}{c}\text { Pre-germination } \\
\text { methods }\end{array}$} & \multicolumn{4}{c}{ Root length $(\mathrm{cm})$} & \multicolumn{3}{c}{ Shoot dry mass $(\mathrm{g})$} \\
\cline { 2 - 8 } & \multicolumn{1}{c}{$\mathrm{S}_{1}$} & \multicolumn{1}{c}{$\mathrm{S}_{2}$} & \multicolumn{1}{c}{$\mathrm{S}_{3}$} & $\mathrm{~S}_{4}$ & $\mathrm{~S}_{1}$ & $\mathrm{~S}_{2}$ & $\mathrm{~S}_{3}$ & $\mathrm{~S}_{4}$ \\
\hline $\mathrm{M}_{1}$ & $27.08 \mathrm{Aa}$ & $8.66 \mathrm{Bb}$ & $22.00 \mathrm{Aa}$ & $25.08 \mathrm{Aa}$ & $1.66 \mathrm{Ab}$ & $0.48 \mathrm{Bc}$ & $2.88 \mathrm{Aa}$ & $2.72 \mathrm{Aa}$ \\
$\mathrm{M}_{2}$ & $22.56 \mathrm{Aa}$ & $27.58 \mathrm{Aa}$ & $12.60 \mathrm{Bb}$ & $27.02 \mathrm{Aa}$ & $1.25 \mathrm{Abc}$ & $1.45 \mathrm{Ab}$ & $0.65 \mathrm{Bc}$ & $2.71 \mathrm{Aa}$ \\
$\mathrm{M}_{3}$ & $27.66 \mathrm{Aa}$ & $32.00 \mathrm{Aa}$ & $26.66 \mathrm{Aa}$ & $27.16 \mathrm{Aa}$ & $1.58 \mathrm{Ab}$ & $0.90 \mathrm{ABc}$ & $2.89 \mathrm{Aa}$ & $1.77 \mathrm{Bb}$ \\
$\mathrm{M}_{4}$ & $26.41 \mathrm{Ab}$ & $32.83 \mathrm{Aa}$ & $24.33 \mathrm{Ab}$ & $23.83 \mathrm{Ab}$ & $1.44 \mathrm{Ab}$ & $1.41 \mathrm{Ab}$ & $2.45 \mathrm{Aa}$ & $2.77 \mathrm{Aa}$ \\
$\mathrm{M}_{5}$ & $24.50 \mathrm{Aab}$ & $28.50 \mathrm{Aa}$ & $23.50 \mathrm{Aab}$ & $22.00 \mathrm{Aa}$ & $1.67 \mathrm{Ab}$ & $1.21 \mathrm{Ab}$ & $2.73 \mathrm{Aa}$ & $3.05 \mathrm{Aa}$ \\
\hline
\end{tabular}

$\mathrm{M}_{1}$ : mechanical scarification with sandpaper and imbibition in water for $24 \mathrm{~h} ; \mathrm{M}_{2}$ : tegument cutting and soaking in water for $24 \mathrm{~h} ; \mathrm{M}_{3}$ : soaking in water for $24 \mathrm{~h} ; \mathrm{M}_{4}$ : seed soaked in water with Trichoderma harzianum for $24 \mathrm{~h} ; \mathrm{M}_{5}$ : seed in water containing T. longibrachiatum for $24 \mathrm{~h}$. Substrates: $\mathrm{S}_{1}: 100 \%$ of soil; $\mathrm{S}_{2}$ : soil + commercial substrate Basaplant Solaris ${ }^{\circledR}(3: 2) ; S_{3}$ : soil + bovine manure $(3: 2) ; S_{4}$ : soil + goat manure $(3: 2)$. * Means followed by the same capital letter in the column and lowercase letter in the row do not differ statistically from each other by the Tukey test at $5 \%$ of probability.

Table 6. Root dry mass and total dry mass in the production of tamarind seedlings, as a function of pre-germination methods and substrates.

\begin{tabular}{|c|c|c|c|c|c|c|c|c|}
\hline \multirow{2}{*}{$\begin{array}{l}\text { Pre-germination } \\
\text { methods }\end{array}$} & \multicolumn{4}{|c|}{ Root dry mass (g) } & \multicolumn{4}{|c|}{ Total dry mass (g) } \\
\hline & $\mathrm{S}_{1}$ & $\mathrm{~S}_{2}$ & $\mathrm{~S}_{3}$ & $\mathrm{~S}_{4}$ & $\mathrm{~S}_{1}$ & $\mathrm{~S}_{2}$ & $\mathrm{~S}_{3}$ & $\mathrm{~S}_{4}$ \\
\hline $\mathrm{M}_{1}$ & $0.58 \mathrm{Bb}$ & $0.30 \mathrm{Bb}$ & $1.16 \mathrm{Aa}$ & $0.57 \mathrm{ABb}$ & $2.25 \mathrm{Ab}$ & $0.78 \mathrm{Bc}$ & $4.04 \mathrm{Aa}$ & $3.29 \mathrm{Aa}$ \\
\hline $\mathrm{M}_{2}$ & $1.03 \mathrm{Aa}$ & $0.83 \mathrm{Aa}$ & $0.20 \mathrm{Cb}$ & $0.78 \mathrm{Aa}$ & $2.28 \mathrm{Ab}$ & $2.29 \mathrm{Ab}$ & $0.85 \mathrm{Bc}$ & $3.50 \mathrm{Aa}$ \\
\hline $\mathrm{M}_{3}^{2}$ & $0.65 \mathrm{Bab}$ & $0.78 \mathrm{Aa}$ & $0.74 \mathrm{Bab}$ & $0.47 \mathrm{Bb}$ & $2.24 \mathrm{Ab}$ & $1.69 \mathrm{Ab}$ & $3.63 \mathrm{Aa}$ & $2.24 \mathrm{Bb}$ \\
\hline $\mathrm{M}_{4}$ & $0.55 \mathrm{Bb}$ & $0.78 \mathrm{Ab}$ & $1.14 \mathrm{Aa}$ & $0.71 \mathrm{ABb}$ & $2.00 \mathrm{Ab}$ & $2.20 \mathrm{Ab}$ & $3.59 \mathrm{Aa}$ & $3.49 \mathrm{Aa}$ \\
\hline $\mathrm{M}_{5}^{4}$ & $0.59 \mathrm{Ba}$ & $0.58 \mathrm{ABa}$ & $0.67 \mathrm{Ba}$ & $0.68 \mathrm{ABa}$ & $2.27 \mathrm{Ab}$ & $1.79 \mathrm{Ab}$ & $3.41 \mathrm{Aa}$ & $3.74 \mathrm{Aa}$ \\
\hline
\end{tabular}

$\mathrm{M}_{1}$ : Mechanical scarification with sandpaper and imbibition in water for $24 \mathrm{~h} ; \mathrm{M}_{2}$ : tegument cut and soaking in water for $24 \mathrm{~h} ; \mathrm{M}_{3}$ : soaking in water for $24 \mathrm{~h}$; $\mathrm{M}_{\text {: }}$ seed soaked in water with Trichoderma harzianum for $24 \mathrm{~h} ; \mathrm{M}_{5}$ : seed in water containing T. longibrachiatum for $24 \mathrm{~h}$. Substrates: $\mathrm{S}_{1}: 100 \%$ of soil; $\mathrm{S}_{2}$ : soil + commercial substrate Basaplant Solaris ${ }^{\circledR}(3: 2) ; \mathrm{S}_{3}$ : soil + bovine manure $(3: 2) ; \mathrm{S}_{4}$ : soil + goat manure $(3: 2) . *$ Means followed by the same capital letter in the column and lowercase letter in the row do not differ statistically from each other by the Tukey test at $5 \%$ of probability. 
mechanically scarified seeds provided seedlings with a lower total dry mass, in relation to the other types of dormancy overcoming. The substrate soil + bovine manure and the seedlings from seeds with tegument cut obtained a lower mass accumulation, and for the substrate soil + goat manure the use of seed imbibition in water presented a lower total dry mass.

Therefore, it was observed that the seeds that were treated with Trichoderma did not present the lowest values of total dry mass, independently of the substrate, in response to the beneficial action of the fungus on the growth of the plant acting on the metabolism of RNA, DNA and plant proteins, activating systemic changes in physiology with stress gene expression and metabolism (Alfano et al. 2007). Mastouri et al. (2010) state that Trichoderma reduces the physiological stress, i.e., low seed quality induced by the aging of the seeds.

The substrates with organic source in the formulation (bovine and goat manure) presented higher accumulations of total dry mass in all the pre-germination methods (Table 6). The substrates with organic formulations have superiority due to the high levels of nitrogen, phosphorus, calcium and magnesium, which contribute to a greater rooting and cellular development of the plant (Taiz et al. 2017). Likewise, Costa et al. (2012) concluded that the substrate with $80 \%$ of soil and $20 \%$ of organic compost was the most suitable for the formation of tamarind seedlings, due to the high values of calcium and magnesium present in the organic compound.

The biomass production was also significantly affected by the evaluated factors, where, in the substrate with only soil, the best pre-germination method was seed soaked in water with $T$. harzianum for $24 \mathrm{~h}$. In the substrate soil + commercial substrate, the tegument cut method provided a greater biomass production, while, in the substrate soil + bovine manure, the dormancy overcoming happened with imbibition in water for $24 \mathrm{~h}$ and seed imbibition in both Trichodermas; whereas, for the substrate soil + goat manure, there was no significant difference among the pre-germination methods for this variable (Table 7).

The behavior observed in the water-imbibed seeds containing the Trichodermas on the production of biomass may be associated to its effect on the plant, which, when colonizing the roots, the epidermis and the cortex cells, stimulates the growth and development of plants, due to the solubilization of phosphate, micronutrients and also by the production of auxin analogues (Carvalho et al. 2011, Silva et al. 2017). In addition, the seedling germination and emergence correspond to the stages of the life cycle of a plant in which it is most vulnerable to environmental stresses and pest and disease attacks. So, seed inoculation with Trichoderma promotes a protection against pathogenic attacks and environmental stresses at this early stage by providing a greater development (Marcos Filho 2005).

Table 7 shows data on the quality of tamarind seedlings. When analyzing the Dickson quality index in the substrate with only soil, there was no significant difference between the pre-germination methods. In the commercial substrate, the physical method of mechanical scarification increased the quality of the seedlings. For the substrate soil + bovine manure, all methods, execept for the tegument cut, were statistically superior. For soil + goat manure, the mechanical scarification, as well as in the use of imbibition of both Trichodermas, increased the quality of tamarind seedlings.

It was observed that, in most substrates, the dormancy overcoming through mechanical

Table 7. Biomass production and Dickson quality index in the production of tamarind seedlings, as a function of pre-germination methods and substrates.

\begin{tabular}{|c|c|c|c|c|c|c|c|c|}
\hline \multirow{2}{*}{$\begin{array}{l}\text { Pre-germination } \\
\text { methods }\end{array}$} & \multicolumn{4}{|c|}{ Biomass production $(\%)$} & \multicolumn{4}{|c|}{ Dickson quality index } \\
\hline & $\mathrm{S}_{1}$ & $\mathrm{~S}_{2}$ & $\mathrm{~S}_{3}$ & $\mathrm{~S}_{4}$ & $\mathrm{~S}_{1}$ & $\mathrm{~S}_{2}$ & $\mathrm{~S}_{3}$ & $\mathrm{~S}_{4}$ \\
\hline $\mathrm{M}_{1}$ & $36.91 \mathrm{Ba}$ & $13.33 \mathrm{Cb}$ & $34.41 \mathrm{Ba}$ & $32.72 \mathrm{Aa}$ & $0.16 \mathrm{Ab}$ & $0.20 \mathrm{Aab}$ & $0.25 \mathrm{Aa}$ & $0.22 \mathrm{Aab}$ \\
\hline $\mathrm{M}_{2}$ & $36.63 \mathrm{Bb}$ & $51.61 \mathrm{Aa}$ & $17.93 \mathrm{Cc}$ & $35.38 \mathrm{Ab}$ & $0.19 \mathrm{Aab}$ & $0.17 \mathrm{ABab}$ & $0.14 \mathrm{Bb}$ & $0.20 \mathrm{ABa}$ \\
\hline $\mathrm{M}_{3}$ & $37.41 \mathrm{Bab}$ & $38.09 \mathrm{Bab}$ & $42.93 \mathrm{Aa}$ & $34.03 \mathrm{Ab}$ & $0.16 \mathrm{Ab}$ & $0.14 \mathrm{Bb}$ & $0.22 \mathrm{Aa}$ & $0.15 \mathrm{Bb}$ \\
\hline $\mathrm{M}_{4}$ & $45.21 \mathrm{Aa}$ & 41.35 Bab & $36.08 \mathrm{ABb}$ & $35.19 \mathrm{Ab}$ & $0.15 \mathrm{Ab}$ & $0.16 \mathrm{ABb}$ & $0.20 \mathrm{Aab}$ & $0.22 \mathrm{Ab}$ \\
\hline $\mathrm{M}_{5}$ & $38.25 \mathrm{ABa}$ & $33.45 \mathrm{Ba}$ & $34.71 \mathrm{ABa}$ & $35.28 \mathrm{Aa}$ & $0.16 \mathrm{Ab}$ & $0.15 \mathrm{ABb}$ & $0.22 \mathrm{Aa}$ & $0.22 \mathrm{Aa}$ \\
\hline
\end{tabular}

$\mathrm{M}_{1}$ : mechanical scarification with sandpaper and imbibition in water for $24 \mathrm{~h} ; \mathrm{M}_{2}$ : tegument cut and soaking in water for $24 \mathrm{~h}$; $\mathrm{M}_{3}$ : soaking in water for $24 \mathrm{~h}$; $\mathrm{M}_{4}$ : seed soaked in water with Trichoderma harzianum for $24 \mathrm{~h} ; \mathrm{M}_{5}$ : seed in water containing T. longibrachiatum for $24 \mathrm{~h}$. Substrates: $\mathrm{S}_{1}$ : $100 \%$ of soil; $\mathrm{S}_{2}$ : soil + commercial substrate Basaplant Solaris $^{\circledR}(3: 2) ; \mathrm{S}_{3}$ : soil + bovine manure $(3: 2) ; \mathrm{S}_{4}$ : soil + goat manure ( $\left.3: 2\right)$. * Means followed by the same capital letter in the column and lowercase letter in the row do not differ statistically from each other by the Tukey test at $5 \%$ of probability. 
scarification, as well as the imbibition in both Trichodermas, showed a higher quality for the tamarind seedlings. Therefore, the seed soaked in Trichoderma may be an alternative in the substitution of the physical scarification method, as it is easier to handle and provides vigorous changes, because these fungi break the hard endocarp and potentially reduce the mechanical resistance to germination in dormant seeds (Delgado-Sánchez et al. 2013). The beneficial function of the fungus inoculation also provides a greater root development and nutritional absorption by plants (Kumar et al. 2017).

\section{CONCLUSIONS}

1. The use of substrates formulated with soil + bovine manure $(3: 2)$ and soil + goat manure $(3: 2)$ in the production of Tamarindus indica L. provides a greater growth;

2. The pre-germination methods of mechanical scarification and the use of seeds soaked in both Trichoderma harzianum and T. longibrachiatum positively influence the quality of tamarind seedlings.

\section{REFERENCES}

ABREU, D. C. A.; PORTO, K. G.; NOGUEIRA, A. C. Métodos de superação da dormência e substratos para germinação de sementes de Tachigali vulgaris L. G. Silva \& H. C. Lima. Floresta e Ambiente, v. 24, n. 1, p. 1-10, 2017.

AGUIAR, A. A. S. et al. Desenvolvimento do milheto sob adubação orgânica no município de Corrente - PI. Revista Verde de Agroecologia e Desenvolvimento Sustentável, v. 7, n. 4, p. 90-96, 2012.

ALFANO, G. et al. Systemic modulation of gene expression in tomato by Trichoderma hamatum 382 . Biological Control, v. 97, n. 4, p. 429-437, 2007.

BASKIN, C. C.; BASKIN, J. M. Seeds: ecology, biogeography, and evolution of dormancy and germination. 2. ed. San Diego: Academic Press, 2014.

CARVALHO, D. D. C. et al. Controle de Fusarium oxysporum f. sp. phaseoli in vitro e em sementes, e promoção de crescimento inicial do feijoeiro comum por Trichoderma harzianum. Tropical Plant Pathology, v. 36, n. 1, p. 28-34, 2011.

CARVALHO, N. M.; NAKAGAWA, J. Sementes: ciência, tecnologia e produção. 5. ed. Jaboticabal: Funep, 2012.
COELHO, M. A.; SONCIN, N. B. Geografia do Brasil. São Paulo: Moderna, 1982.

COSTA, E. et al. Diferentes composições de substratos e ambientes protegidos na formação de mudas de pé-franco de tamarindeiro. Revista Brasileira de Fruticultura, v. 34, n. 4, p. 1189-1198, 2012.

DANTAS, A. C. V. L. et al. Effect of gibberellic acid and the biostimulant Stimulate ${ }^{\circledR}$ on the initial growth of tamarind. Revista Brasileira de Fruticultura, v. 34, n. 1, p. 8-14, 2012.

DELGADO-SÁNCHEZ, P. et al. Are fungi important for breaking seed dormancy in desert species?: experimental evidence in Opuntia streptacantha (Cactaceae). Plant Biology, v. 13, n. 1, p. 154-159, 2011.

DELGADO-SÁNCHEZ, P. et al. Effect of fungi and light on seed germination of three Opuntia species from semiarid lands of central Mexico. Journal of Plant Research, v. 126, n. 5, p. 643-649, 2013.

DELGADO-SÁNCHEZ, P. et al. Further evidence from the effect of fungi on breaking Opuntia seed dormancy. Plant Signaling \& Behavior, v. 5, n. 1, p. 1229-1230, 2010.

DICKSON, A.; LEAF, A. L.; HONER, J. F. Quality appraisal of white spruce and white pine seedling stock in nurseries. Forestry Chronicle, v. 36, n. 1, p. 10-13, 1960.

EMON, R. M. et al. Morpho-genetic screening of the promising rice genotypes under salinity stress. Journal of Agricultural Science, v. 7, n. 5, p. 94-111, 2015.

EMPRESA BRASILEIRA DE PESQUISA AGROPECUÁRIA (Embrapa). Manual de métodos de análise do solo. 2. ed. Rio de Janeiro: CNPS/MAPA, 1997.

FERREIRA, D. F. Sisvar: a guide for its bootstrap procedures in multiple comparisons. Ciência e Agrotecnologia, v. 38, n. 2, p. 109-112, 2014.

FRANÇA, D. V. C. et al. Isolados de Trichoderma spp. com potencial de solubilização de fosfato e promoção de crescimento em tomateiro cereja. Pesquisa Agropecuária Tropical, v. 47, n. 4, p. 360-368, 2017.

FRANCISCO, P. R. M.; SANTOS, D. Climatologia do estado da Paraíba. Campina Grande: Ed. UFCG, 2017.

GÓES, G. B. et al. Métodos de enxertia na produção de mudas de tamarindeiro. Revista Ceres, v. 63, n. 6, p. 853859, 2016.

GOMES, J. P. et al. Caracterização morfológica de plântulas durante a germinação de sementes de Psidium cattleianum e Acca sellowiana (Myrtaceae). Ciência Florestal, v. 25, n. 4, p. 1035-1042, 2015.

HARMAN, G. E. et al. Trichoderma species: opportunistic, avirulent plant symbionts. Nature Reviews: Microbiology, v. 2, n. 1, p. 43-56, 2004. 
JUNGES, E. et al. Trichoderma spp. na produção de mudas de espécies florestais. Floresta e Ambiente, v. 23, n. 2, p. 237-244, 2016.

KUMAR, K.; MANIGUNDAN, K.; AMARESAN, N. Influence of salt tolerant Trichoderma spp. on growth of maize (Zea mays) under different salinity conditions. Journal of Basic Microbiology, v. 57, n. 2, p. 141-150, 2017.

LIMA, J. S. et al. Métodos de superação de dormência em sementes de flamboyant (Delonix regia). Revista Verde de Agroecologia e Desenvolvimento Sustentável, v. 8, n. 1, p. 104-109, 2013.

MACHADO, D. F. M. et al. Trichoderma no Brasil: o fungo e o bioagente. Revista de Ciências Agrárias, v. 35, n. 1, p. 274-288, 2012.

MARCOS FILHO, J. Fisiologia de sementes de plantas cultivadas. Piracicaba: Fealq, 2005.

MASTOURI, F.; BJÖRMAN, T.; HARMAN, G. E. Seed treatment with Trichoderma harzianum alleviates biotic, abiotic, and physiological stresses in germinating seeds and seedlings. Phytopathology, v. 100, n. 11, p. 12131221, 2010.

MENDONÇA, V. et al. Avaliação de diferentes substratos na produção de porta-enxertos de tamarindeiro. Revista Caatinga, v. 27, n. 1, p. 60-66, 2014.

MESQUITA, E. F. et al. Produção de mudas de mamoeiro em função de substratos contendo esterco bovino e volume de recipientes. Revista Brasileira de Ciências Agrárias, v. 7, n. 1, p. 58-65, 2012.

OLIVEIRA, E. P. et al. Superação de dormência em sementes de Tamarindus indica L. submetidas a diferentes tratamentos pré-germinativos. Revista Cientifica Eletrônica de Agronomia, v. 32, n. 1, p. 1-6, 2017.

PEREIRA, E. C. et al. Growth and levels of N, P and K in rootstocks of tamarind trees using organic substrates and doses of phosphorus. Revista Caatinga, v. 29, n. 2, p. 274-282, 2016.

REPAS, T. S. et al. Growing plants on oily, nutrient-poor soil using a native symbiotic fungus. Plos One, v. 12, n. 10, p. 1-15, 2017.

SEGATO, S. V.; MUNDURUCA, L. C.; SOUZA, V. M. S. Sanidade de sementes e emergência de plântulas de sementes de Tamarindus indica submetidas a diferentes tratamentos pré-germinativos. Revista Nucleus, v. 14, n. 1, p. 237-246, 2017.

SILVA, F. F. et al. Emergência e análise ultraestrutural de plântulas de soja inoculadas com Sclerotinia sclerotiorum sob efeito da aplicação de Trichoderma harzianum. Summa Phytopathologica, v. 43, n. 1, p. 41-45, 2017.

SOUZA, F. M. et al. Crescimento inicial do milho sob doses de esterco caprino e disponibilidade de água no solo. Revista Verde de Agroecologia e Desenvolvimento Sustentável, v. 12, n. 2, p. 241-245, 2017.

SOUZA, M. D.; FERNANDES, R. R.; PASA, M. C. Estudo etnobotânico de plantas medicinais na comunidade São Gonçalo, MT. Biodiversidade, v. 9, n. 1, p. 91-100, 2010.

SURALKAR, A. A. et al. Evaluation of anti-inflammatory and analgesic activities of Tamarindus indica seeds. International Journal of Pharmaceutical Sciences and Drug Research, v. 4, n. 3, p. 213-217, 2012.

SWAIN, H. et al. Novel Trichoderma strains isolated from tree barks as potential biocontrol agents and biofertilizers for direct seeded rice. Microbiological Research, v. 214, n. 1, p. 83-90, 2018.

TAIZ, L. et al. Fisiologia e desenvolvimento vegetal. 6. ed. Porto Alegre: Artmed, 2017.

YUAN, T. et al. Fertilizer potential of liquid product from hydrothermal treatment of swine manure. Waste Management, v. 77, n. 1, p. 166-171, 2018. 